\title{
抵抗線歪計式咬合力測定装置の考案
}

小山正宏*五十嵐孝義高見沢忠
榎沢

\section{A Design of New Apparatus for Measuring Bite Force using Foil Strain Gauges}

\author{
Masahiro Koyama, Takayoshi Igarashi, Tadashi Takamizawa, \\ Kenji Enosawa, Yasuharu Kasai, Yoshihiko Moriya*
}

精度が高く, 疲労が少く、しかも防湿, 温度補償の点 で、満足のゆく咬合力測定装置を考案し，完製した.こ れはフォイルストレーンゲージを応用した電気的測定法 の 1 法である.

每牙は元来咀礵器官である以上, 咬合力測定は生理学 上および歯科臨床上，非常に有意義なものである。その 意味で歷史的にみると， 70 年前よりこの目的逐行のた めに幾多の方法, 装㯰が考案, 発表, 追試されている. これらは原理的には次の 5 つに分類される.

1）発条式によるもの.

2）槓杆作用によるもの.

3）油圧によるもの.

4）ブリネル硬度によるもの.

5）電気的変化によるもの.

以下この順序に従い，年代順に先人の業蹟を通㹂して みる.

1）発条式によるもの.

1893 年すでに Dennis ${ }^{251}$, Patrick' ${ }^{19)}$ につて, 咬合力 測定の本格的研究が始められた. それ以前に Borelli" (1681 年), Burras" (1861 年), Sigmund ${ }^{39}$ (1871 年), Sauer ${ }^{33)}$ (1891 年), Fenchel" (1901 年), Arnone ${ }^{221}$ (1906 年), Reschofsky" (1906 年), Müller - Max ${ }^{3 n}$ (1912 年), Müller · Adolf'（1914 年)，等が人間の咀覆 圧 (masticating pressure $\cdot$ bite pressure) の数值を呈示し ているが、いずれもその值はまちまちで本格的な測定装 置は見当らない，そして1893 年 Dennis は咀絪圧測定

* Graduate School (Major in Prosthetics) Nihon University School of Dentistry' (Director : Prof. Setsuzõ Okino) 日本大学大学院歯学砂究科（䋠稀学尃攻） (指道 沖野節三教授)
について講演を行い，注意を換起した．翌 1894 年に Black 23201 は Dennis の装置を改良して，発条の歪によ りカの大きさを測る器械を作つて測定を行い, 咀嘈力 (masticating force•bite force) は個人の習慣，歯䯙拈上 び药根膜の状態によつて異る事を述べた，なお特有の装: 置 (Phagodynamometer) を作り，食物の咀嘌にいかほど の瓜力を要するかを測定した. 1913 年に Morelli"36はV 字に届曲した弾力線の両端を咬合させ, 両線の中央部の 圧縮度を度盛板上の指針で咬合圧 $(\mathrm{kg})$ として読み取つ た. 1916 年に Hentze ${ }^{19}$ は Morelli は弾力板の一端に 咬合部を設けたのに反し氏は棛円形弾力板の中央に咬合

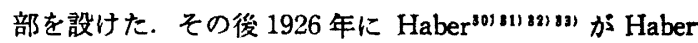
氏 Gnathodynamometer を考案，発表している.この 装置の構成は，ゴム膜でおおわれた 2 枚の咬合板 $(15 \times$ $19 \mathrm{~mm}$ ) と他端の度盛板から成つている，以来本装置は 幾多の学者により追試され, 実際の咀濖圧測定に害与し た.しかし、, Greve 2"121291 および Münzcschemer" 氏ら の実験により，その久点が指摘された，つまり咬合圧が. 咬合板上に加わる力の位直により大いに異る点である.

日本においては，岡田・富取”（1929 年）(Habet の Gnathodynamometer 使用), 内山有注 ${ }^{23)}$ (1932 年) (Haber の Gnathodynamometer 使用), 传藤昌朝"' " (1935 年) (Haber 氏測定器を改良した SY 式咬合器を紹介し た). 佐藤峰雄 ${ }^{19}$ (1941 年), 黑沢佐太郎" (1956 年) (佐藤 氏の SY 式咬合力測定器を探用して測定している), 村松第良・塩川延洋・三宅聡・高木米一1811711" (1952, 1957 年), 吉村信善・吉田達也・野瀬清 ${ }^{201}$ (1959 年)（力 量調節式の発条式咬合力測定器を使用して下額大日歯の 咬合力を測定した), 細川貞雄1!'(1959 年), 長野三代太 (1959 年)（細川同様の発条式を利用して乳歯の咬合力平 
抅 $4 \mathrm{~kg}$ を湖定した)斿が発条式によるものを使用した.

2）概仠作用によるもの.

Rosenthal"（1896 年) (関節にて結合せる植杆に分銅を 吊して測定した)，Eckermann ${ }^{26)}$ (1911年)，木本信義" (1957年) (金属の咬合部を合成㯕脂で被覆)，林木栄・伊 藤秀三郎 $\left.{ }^{13)}\right)$ (1958年)，小西繁一" (1959 年) (鋼䌘の受圧 部をゴムで被覆）等があるが，三浦 ${ }^{15}$ は槙杆作用による にのは受圧部を瞬間的に咬合させると、多分に開口によ る下頻自体の加速度が加わり以外に大きな值を示すとい らことを指摘している.

3）油圧によるもの.

Schwander-Lickleig", Dieck' ${ }^{191}$ (1909年)の測定器は気 左計を応用した弓状管よりなり。その中に液体を入れ た. 管は度盛板に乫出し，先端に咬合部を有す．これに 压力を加えると管上端にある球頭桿を圧下する．この時 管内の液体は圧下され指針を移動させる. Howard K, Worner ${ }^{411}$ (1954 年) ( 1 歯対 2 歯の咬合関係のもとで測定 レた咬合力と上下同名歯間で 1 対 1 歯の咬合関係で測定 した値との比較）等によつて使用されている.

4) Brinnel 硬度によるもの.

Schönwald" (1921 年)，Günther" (1920年)，KöhlerEtling"(1922年), Oande R. Baker ${ }^{19)}$ (1940年), P. J. Brekhas ${ }^{19}$ ， R. L. Dowell199 等によつて使用されている.

5) 電気的変化によるもの.

Man|y ${ }^{251}$ (1948年) (Inductance method によるもの で、ゾンデおよび增巾器が不安定のため0点が狂う), Howel| ${ }^{35)}$ (1950 年), 石河圭介" (1950 年) (水晶 X-cut Piezo 電気応用), 三浦不二夫・角田正明101111151（1951 年) (高周波利用による Condenser-method), Anderson ${ }^{21}$ (1953 年) (ジンデを用うることなく，直接被検者の金冠 内に抵抗線歪計を封入する方法を用いたが，安定性が不 充分であった）等によって測定が試みられたが，いずれ も満足なものではなかつた。

\section{自家考案の測定装置の構造}

著者らの考案した測定装置はフォイルストレーンゲー 淁を応用し，安定化をはかつた電気的測定法である.

本装置はモニターブラウン管オシロスコープ, 前置増 巾器, 主增巾器および記録器より構成される(図 1 a).

前圆增巾器はプラグインオ式により 4 種類に使い分け ることができ, 著者らは歪・圧力計用增巾器を使用し た. その原理は次の通りである. まずトランスジューサ 一となるバイトエレメントにカを加えると，その力に比 例して内部のブリッジ回路に電圧のアンバランスを生ず る.そこで出されたわずかな電圧が前置增巾器に入る. 增巾された出力は一方ではブラウン管オシロスコーブ上

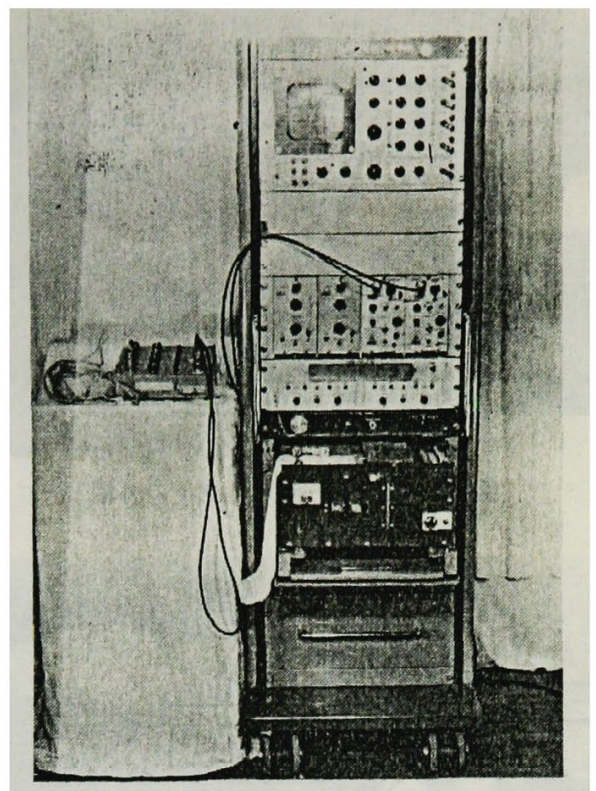

图 1 a 湘定装置 (多用途監視記録装置) の正面観

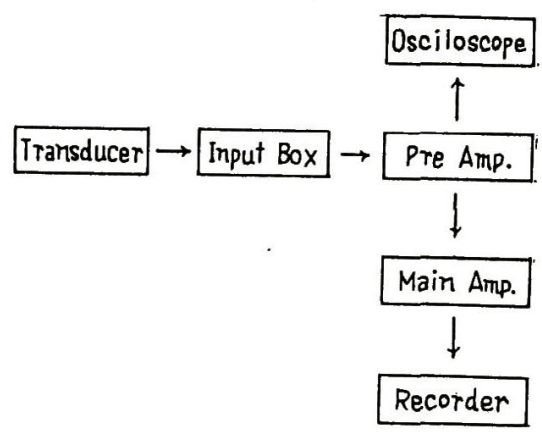

図 1 b 測定装置(多用途監視記録装置) の系統図

にて波形として観察され，他方同じ出力が主增巾器に入 り，更に増巾されてインク書きオシログラフにて記録さ れる(図1 b).

バイトエレメントはゲージベースがステンレススチー ルで，大きさは直径 $20 \mathrm{~mm}$ ，厚さ $12 \mathrm{~mm}$ である．測定 筑囲は最大 $150 \mathrm{~kg}$ まで测定出来る、精度の測定はアム スラー型荷重試呀機にて行つた．製作にあたつては次の ことに考慮を払つた．まず一般的な条件として次の 4 項 目すなわち

(1) 温度補倓が完全に行われること.

(2) 測定筑囲が十分であること.

(B) クリープを最小にすること. 


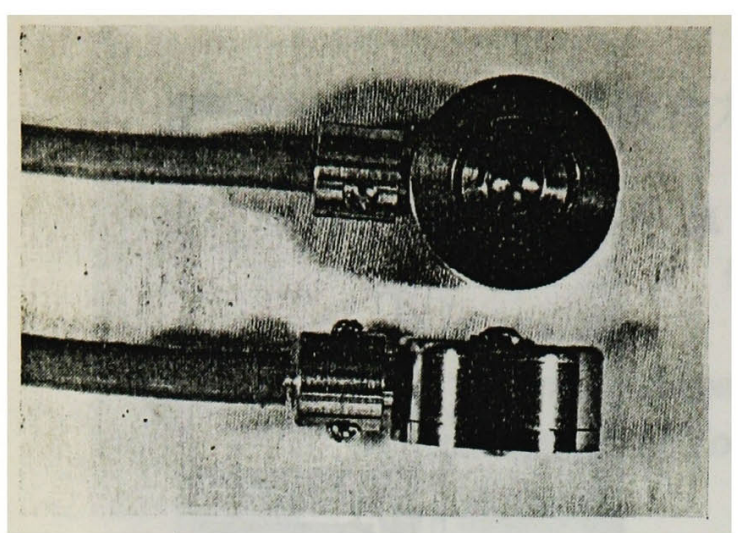

図 2 a パイトェレメントの外钼

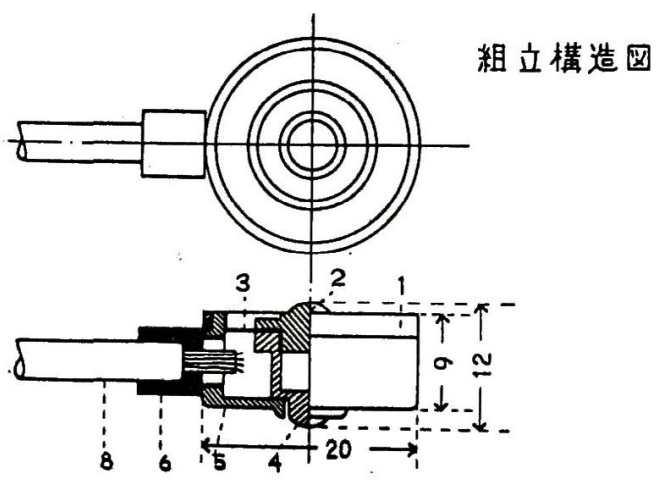

图 2 b バイトェレメントの内部權造

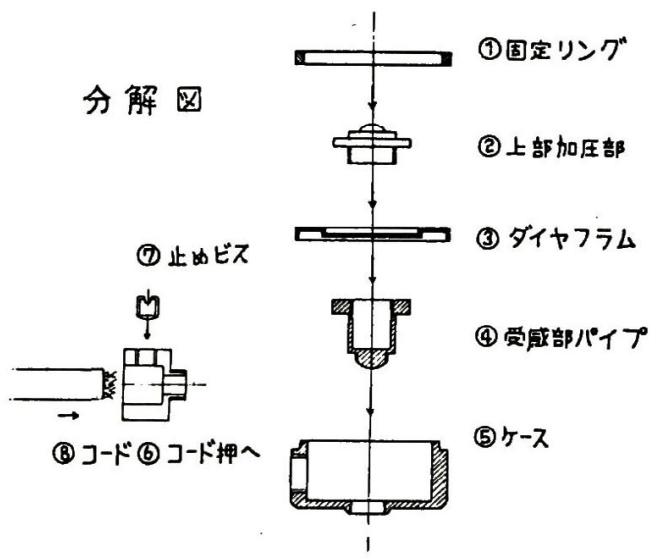

図 2 c パイトエレメントの分解图

(4) 絶縁性の高いこと.

に考㤫を払い，さらに口腔内操作という特殊条件に適合 するために次の 4 項目すなわち，

(1) 形, 大きさが咬合部に適台し女定すること.
(2) 防湿が完全であること.

(3)咬合力によつて疲労したり，破壊されないこと.

(4) 軽いこと $(16.0 \mathrm{~g})$.

等に考虑を払つた(図 $2 a$, 图 2 b).

バィトエレメントの内部を更に分解すると，中央のス テレンススチールのパイプの周围に 4 枚のフォイルスト レーンゲージをアラルダイトを使用して貼つてある.こ の 4 枚のフオイルストレーンゲージによつてホィートス トンブリッジ回路を構成し，パイプの綐横両方の昰を感 受し大きな感度を得ると同㭙に温度補償を完全に行つて いる(図 2 c).

フォイルストレーンゲージ(図 3) は比胶的歴史の新し いもので, アドバンスといら銅ニッケル合金で作られて 、る. 著者らは艮さ $1.0 \mathrm{~mm}$, 巾 $1.6 \mathrm{~mm}$ とい5日本最 小のものを採用した. ゲージを貼有してあるパイプが棑 むと,ゲージ自身も歪むので,電気抵抗に变化を生ずるわ けである.このゲージ全体の抵抗は 60 オームである. 従来のワィヤーストレーンゲージにくらべた時の利点と しては，小型に作れることと，この折返しの部分が広い ので，横感度による誤差が少いということ等である．更 に上下䅡の間隔を任意に調節する目的で，バイトエレメ

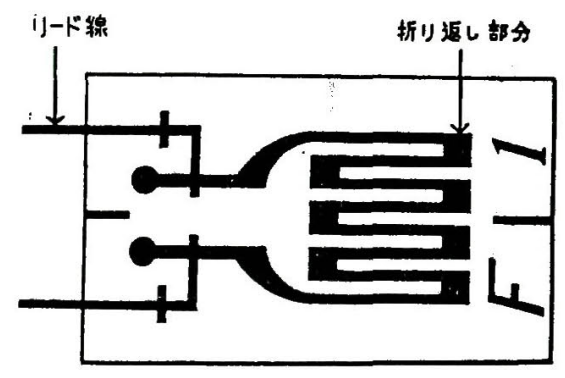

図 3 フォイルストレーンゲージ

ントにとりつけるアダプターを製作した．固定性アダズ ターは厚さ $5 \mathrm{~mm}, 10 \mathrm{~mm}, 15 \mathrm{~mm}, 20 \mathrm{~mm}$ の 4 種であり、 非固定性アダプターはネジにより自由に高さを变えられ るもので 5 種㪇作し $3 \mathrm{~mm}$ より $30 \mathrm{~mm}$ まで㒛節出来る (図 4 a, 図 4 b).

なお著者らは咬合力という言莱を使用しているが,こ の点について少し颜明する，一般に日常咬合圧という文 葉をよく用いるが，圧というと啴位面積をもつて表わさ なくてはならないこレと，物理学的に水圧とか気圧とか いつたハイドロスターティックな力を进想しやすいとい

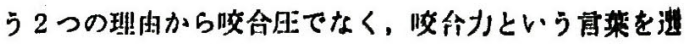

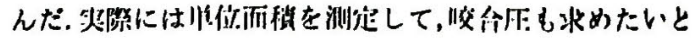




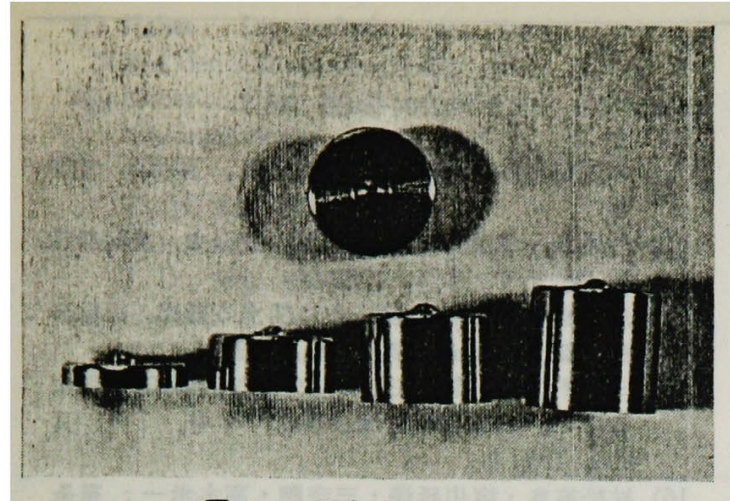

図 4 a 固定性アダプター

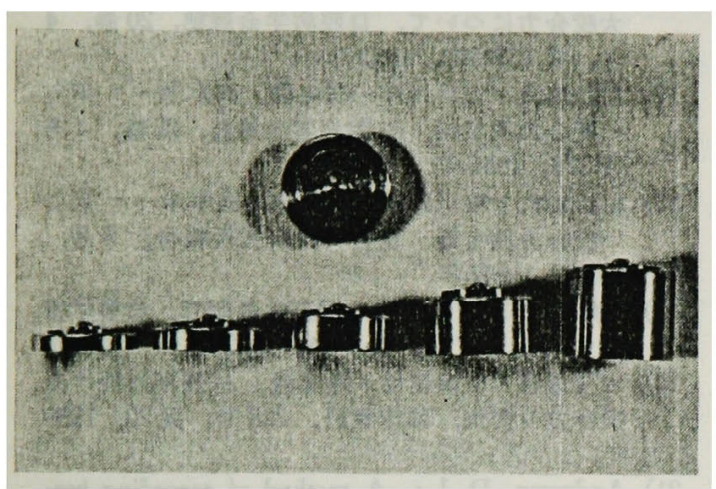

図 4 b 非固定性アダプター

ころであるが，バイトエレメントの方は面積の単位が求 まるとしても，それに接する歯牙の表面積を正確に求め ることは現在のところ困難であるし，その上実際に力を 受ける場合には咬合面よりる，歯根膜の表面積が関連し てくるわけで, 一層複雑な条件となつて来るので, 現在 のところ咬合力の測定にとどまつて, 単位は重量 $(\mathrm{kg})$ をもつて表わした.

正常咬合で健常歯牙を有する 成年男子 20 名につき, 本装置を用いて，上下の 1 対 1 歯の咬合による最大咬合 压を測定した(図 $5 \mathrm{a}$, 図 $5 \mathrm{~b}$ ).

グラフの $1 \mathrm{~mm}$ の高さが $2 \mathrm{~kg}$ に相当するよ5に較正

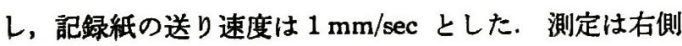
第二大臼より始まり，左側第二大臼菊に終らせた（図 $6 \mathrm{a}$, 図 $6 \mathrm{~b})$.

測定に際しては珓台部に疼痛を感ずる程度まで, 出来 る限り閉口させ,その㭙の値を 5 回記録し，その平均値 をるつて咬合力とした. 図 7 はその結果を示す.

今後本装置を，1）20代の正常齿列者の 各歯牙別の咬 合力, 2) 無骾崡に咬合力, 治療効果をあらわした自然 齔の咬合力, 3) 乳歯の咬合力, 4) Bridge, Crown, 局 部義画，総義蒛の咬合力の測定に応用する計画である.

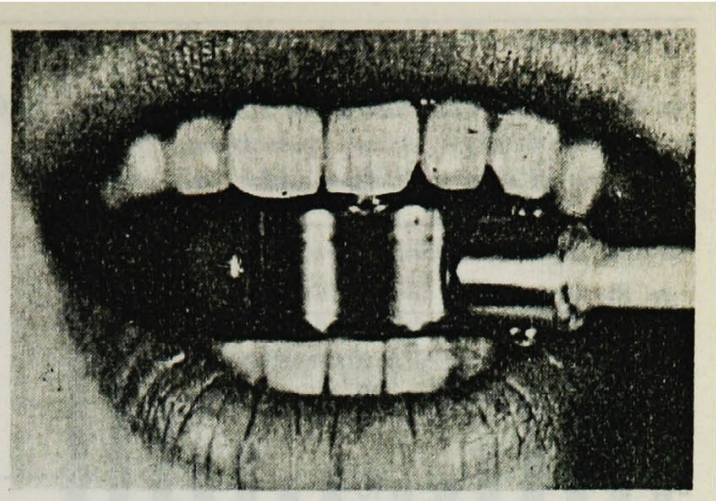

图 5 a 前歯の咬合力测定

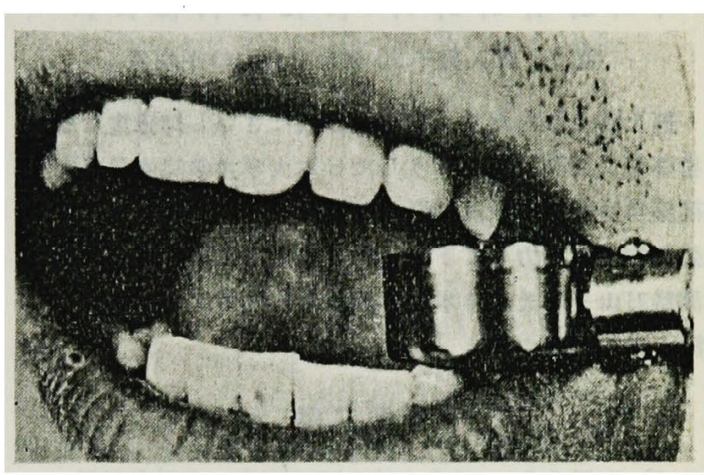

图 5 b 臼药の咬合力測定

被険者 $\mathrm{A}$ 占 $24 \mathrm{j}$

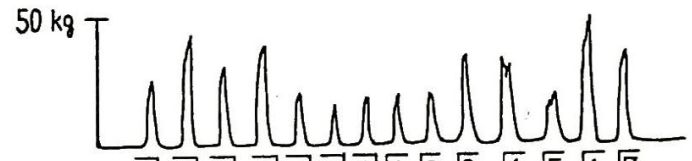

7) 6 , $5,4,3,2$, $1 / \sqrt{1} \sqrt{2} \sqrt{3} \sqrt{4} \sqrt{5} \sqrt{6} \sqrt{7}$

図 6 a ペ書きオシログラフ

被挨者 B $023 j$

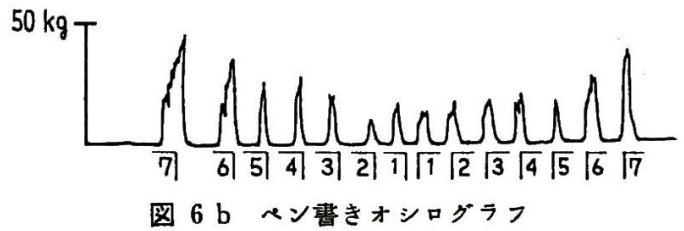




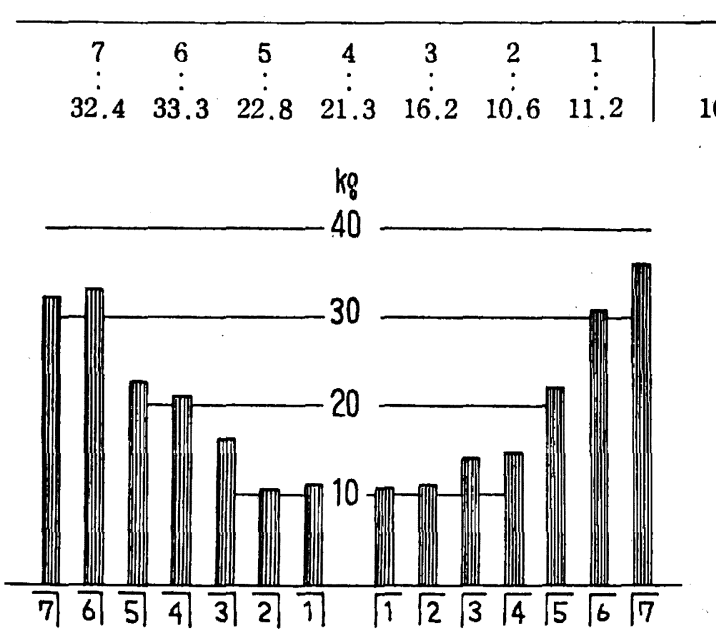

图 7 成人男子 20 例の晈合力の平均值

稿を終るにあたり，本論文作成にさいし御想篤なる御 指学および御校閲を唇うした日本大学大学院歯学研究科 補㥪学沖野節三教授に深甚なる敬意を表し，あわせて本 装置作製に協力して下さった日本光霍工業户崎氏，昭和 测器石山一郎氏, 日本大学理工学部田中武久氏に奶して 深く謝意を表する.

\section{参考文献}

1）石河圭介：日本人咬合圧の破究，歯科学雑誌, 7 巻, 7 号, 頁 316,1950 年.

2) 内山有三：邦人齿牙の阻爝圧, 日本歯科口腔科 学会雑誌, 50 号, 頁 18, 1933 年.

3) 内山有三: 邦人歯牙の咀嚼圧, 口腔科学会雑誌, 5 巻, 7 号, 頁 173, 1933 年.

4) 川上政雄 : 咀獣圧, 附ハーベル氏測定器に就て, 口腔病学会雑誌, 第 2 巻, 第 1 号, 頁 15,1928 年.

5）木本信義：電気衔撃療法の際の歯牙障害に関す 万臨床掬科学的生理学的研究 (2), 歯科学報, 57 巻, 4 号, 頁 146,1959 年.

6) 黒沢佐太郎：日本人女子生徒の握力及び咬合 力，齿科月報， 29 巻，4号，頁 $252 ， 1956$ 年.

7）小西慗一：人歯牙の健全菌及び諸種疾患並に補 数に於ける咬合圧に関する䂙㠰，日本口腔科学 会雑誌, 8 巻, 4 号, 頁 427, 1959 年.

8）佐藤昌朝：咬圧力 (咀嚼力) 測定の意義, 日本之 齿界, 178 号, 頁 27-31，1934 年.

9）佐藤昌朝：咬合玨力に関する私見，学校蒾科， 1 巻, 1 号, 頁 28,1935 年.

10）角田正明・三浦不二夫：咀嚼力の測定，日本齔 科医師会学術会議会誌, 頁 22-23，1950 年.

11）角田正明・三浦不二夫：咀緭力の測定, 日本生 理学雑誌, 13 巻, 1-2 号, 頁 116, 1951 作.

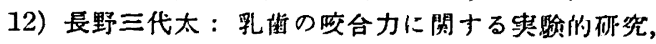

$\begin{array}{cccccccc}1 & 2 & 3 & 4 & 5 & 6 & 7 & \ldots \cdots \\ 10.8 & 11.2 & 14.1 & 14.9 & 22.0 & 30.9 & 36.7 & \cdots \cdots \cdots \\ \end{array}$

九州齿科学会雑誌, 13 巻, 3 号, 頁 403, 1959 年.

13）林木栄・伊藤秀三郎：幼児の咬合力，齿科学豨， 58 卷, 5 号, 頁 1, 1958 作.

14）細川貞雄：齿牙の咬合力に関する研究，医学研 究, 29 巻, 8 号, 頁 2915,1959 年.

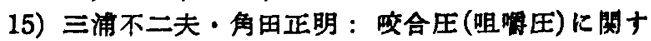
了研究, 日本歯科医師会雑誌, 7 巻, 7 号, 頁 293,1954 年.

16）村松篤主・塩川延洋・三宅諰・高木米一：発条 式咬合力測定器で測定した下顆第 1 大曰齿の最

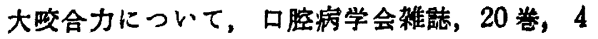
号, 頁 157-162，1953 年.

17）村松第飠・塩川延洋・三宅聰・高木米一：新し 、咬合力湘定器，口腔病学会雑誌， 22 巻， 4 号, 頁 278,1955 年.

18）村松篤良・塩川延洋・三宅偲・高木米一：新し 以咬合力湘定器, 歯科材料研究所赧告, 8 号, 101 頁, 1957 年.

19）矢崎正方：下額運䖝の解剖学的研究，齿科学報, 第 34 巻，第 7 号，頁 1-31，1927 年.

20）吉村信亳・吉田達也・野瀬清：成長期に於ける 咬合力の変化, 臨床歯科, 223 号, 頁 20,1959 年.

21) Anderson, D. J. : A method of recording tma. sticatory loads, J. D. Res., $32: 785-789,1953$.

22) Arnone: Dinamometro oris, Dent. Cosmos, H., 4, 428, 1908.

23) Black: An investigation of the physical chatakters of human teeth in relatibn to their tiseases and to practical dental bperations, together with the physical charakters of filling-tindterials, Dent. Cosmos, 5-9, 1895.

24) Black: The force exerted if the closute of jaws, Dent. Cosmos, 37 : 469-484, 1895.

25) Dennis : Bericht über den zahtuarztlichen Weltkongress in Chicago, D. M. f. Z., H. 3, 1893.

26) Eckermann: Physiologische Bedeutung der kieferbelastung und ihre Ermessung, D. M. f. Z., H. 9, 1911.

27) Greve : Haberscher Kaudruckmesser, D. M. f. Z., H. 17, 1926.

28) Greve: Des Ergebinisse meinet Prifung des Haberschen Kaudruckmesser, Zahnärt. R. H. 48, 1926.

29) Greve : Schlutzbemerkungen auf Habers Entgegung zur Prúfung seines Kaudruckmessers, D. M. f. Z., H. 23, 1926.

30) Haher: Kaudruckmessopparate, Zahnalrzt. R. H. 7-9, 1927. 
31) Haber: Die Aufgaben der Kaudruckmessung und der Zahndruckprüfung, 1926. Berlin.

32) Haber : Uber Ergebnisse mit dem Haberschen Kaudruckmesser, Zahnärzt, R. H. 28-49, . 1927.

33) Haber : Habersche Kaudruckmesser, D. M. f. Z., H. 23, 1926.

34) Howard K. Worner : Gnathodynamics, Austr. J. D., 381, 1959.

35) Howell, A. H. and Manly, R. S. : An electric strain gauge for measuring oral forces, $\mathrm{J}$. D. Res. $27: 6,705-712,1948$.
36) Morelli : Über Kaudruck. W. Vierteljahrsschrift. f. Z., H. 4, 1920.

37) Müller Max: Über die Hebelverhältnisse unsers unterkiefers, seine Vorschiebebewegung und den Schneidezahnführungsstift, am Artikulator, D. M. f. Z., H. 10, 1912.

38) Sauer: Mit wieviel gewicht beitzt $d$. Menschen, D. M. f. Z., H. 2, 1891.

39) Sigmund : Die Kraftleistungen der Zähne, Deutsch, Viertejahrschr. f. Z., H. 2, 1871. 